\title{
Targeted therapy and hematological malignancy
}

\author{
James O. Armitage
}

Received: 12 December 2008 / Accepted: 22 December 2008 / Published online: 14 February 2009

(C) Springer-Verlag 2009

The concept of chemotherapy directed at a specific target can be traced back to Paul Ehrlich [1]. He coined the term "magic bullets" to describe a therapy that would kill a microorganism but leave a patient unharmed. This same concept is the goal, today, of chemical treatments for cancer.

Today treatments are usually described as either being derived empirically or being targeted to attack a particular molecular target in a cancer. Thus, targeted therapies are those where the presumed target is known before the development of the drug in contrast to empirical treatments where the target may not be known even after the effectiveness of the drug or drugs has been proven. However, it is important to remember that effective treatments that have been developed empirically must be hitting important metabolic targets in the cancer cells for them to be effective. It is also true that treatments derived to hit a particular target can have a disappointing outcome despite their theoretical effectiveness. For example, drugs targeted at bcl-2 in hopes of inhibiting a block in apoptosis in cancer cells have to date been disappointing [2].

Some of the greatest successes of empirical therapies have been in the treatment of hematological malignancies. In the 1960s the concept of combination chemotherapy was developed and applied using drugs whose targets were unknown or uncertain. However, the principles including combining drugs with non-overlapping toxicities, combining drugs from different classes of agents (e.g., alkylating agents and vinca alkaloids), and using drugs that could be given in close to full doses as part of a combination have

\section{J. O. Armitage $(\square)$}

Section of Oncology,

Hematology University of Nebraska Medical Center,

Omaha, NE 68198-7680, USA

e-mail: joarmita@unmc.edu been vindicated in numerous clinical trials. In addition, these combined therapies were administered in pulses with periods of time off therapy allowing toxicity to dissipate. Patients who seemed to achieve a complete remission were then followed without therapy. This approach, the result of considerable clinical research, was successful in curing childhood leukemia [3], Hodgkin lymphoma [4], and some non-Hodgkin lymphomas $[5,6]$.

Many of the most effective drugs developed to hit a specific molecular target have also been most effective in hematological malignancies. These include antibodies directed against CD20, small molecules that inhibit bcrabl protein, protease inhibitors, and antibodies directed against CD52. Rituximab, a humanized monoclonal antibody directed at CD20, has been the most important addition to the treatment of patients with B-cell lymphomas developed for the last several decades and has dramatically increased the cure rate for patients with the most common non-Hodgkin's lymphoma - diffuse large B-cell lymphoma $[7,8]$. In the landmark trial the 5-year survival increased from $45 \%$ to $58 \%$.

Imatinib, a small molecule directed against the bcr-abl protein, has completely changed the course for patients with chronic myelogenous leukemia and has become the standard therapy. Imatinib has made it possible to hope that some patients might be cured. The experience with this drug and newer tyrosine kinase inhibitors active in chronic myelogenous leukemia is reviewed in this volume by Jabbour et al.

Bortezomib, a protesome inhibitor, has been one of the new drugs that dramatically have improved our ability to treat patients with multiple myeloma. Using bortezomib and other new agents such as lenidomide the complete response rate and survival are dramatically improving for patients with multiple myeloma. 
Alemtuzumab, an antibody directed against CD52 on the surface of lymphoid cells, has not had the same impact as rituximab but has improved our ability to treat patients with chronic lymphocytic leukemia. As reviewed by QuintasCardama and O'Brien in this issue of Targeted Oncology, alemtuzumab seems particularly active in patients with poor risk genetic findings.

As illustrated in two articles in this issue of Targeted Oncology, new, targeted treatments have had a major impact in the management of patients with hematological malignancies. Once again, principles that are found to be true in the management of patients with hematological malignancies will, hopefully, be applied in carcinomas in a way that will improve survival and cure rates.

\section{References}

1. Androutsos G (2004) Paul Ehrlich (1854-1915): founder of chemotherapy and pioneer of haematology, immunology and oncology. J BUON 9:485-491
2. Klasa RJ (2004) Targeting the proapoptotic factor Bcl-2 in nonHodgkin's lymphoma. Oncology (Willist. Park NY) 18(13 Suppl 10): 25-31

3. Pinkel D (1979) The ninth annual David Karnofsky Lecture. Treatment of acute lymphocytic leukemia. Cancer 43(3):11281137

4. DeVita VT Jr, Simon RM, Hubbard SM, Young RC, Berard CW, Moxley JH 3rd et al (1980) Curability of advanced Hodgkin's disease with chemotherapy. Long-term follow-up of MOPP-treated patients at the National Cancer Institute. Ann Intern Med 92(5): 587-595

5. Levitt M, Marsh JC, DeConti RC, Mitchell MS, Skeel RT, Farber LR et al (1972) Combination sequential chemotherapy in advanced reticulum cell sarcoma. Cancer 29(3):630-636

6. DeVita VT Jr., Canellos GP, Chabner B, Schein P, Hubbard SP, Young RC (1975) Advanced diffuse histiocytic lymphoma, a potentially curable disease. Lancet 1(7901):248-250

7. Coiffier B, Lepage E, Briere J, Herbrecht R, Tilly H, Bouabdallah $\mathrm{R}$ et al (2002) CHOP chemotherapy plus rituximab compared with CHOP alone in elderly patients with diffuse large-B-cell lymphoma. N Engl J Med 346(4):235-242

8. Feugier P, Van Hoof A, Sebban C, Solal-Celigny P, Bouabdallah R, Ferme $\mathrm{C}$ et al (2005) Long-term results of the R-CHOP study in the treatment of elderly patients with diffuse large B-cell lymphoma: a study by the Groupe d'Etude des Lymphomes de l'Adulte. J Clin Oncol 23(18):4117-4126 